\title{
A Holy Alliance: Collusion in the Renaissance Europe Alum Market
}

\author{
Andrea Günster ${ }^{1} \cdot$ Stephen Martin $^{2}$
}

Published online: 31 May 2015

(C) Springer Science+Business Media New York 2015

\begin{abstract}
On June 11, 1470, representatives of Pope Paul II and Ferdinand, King of Naples concluded a cartel agreement to restrict competition in the sale of alum. The agreement was one element of a broader plan to monopolize the sale of alum throughout Christendom. We discuss the background of the cartel agreement and analyze its terms (which include arrangements to facilitate detection of and reduce the profitability of defection) and the constraints that limited, but did not eliminate, Rome's ability to extract economic profit from the European alum market.
\end{abstract}

Keywords Cartels $\cdot$ Collusion $\cdot$ Alum

JEL Classification D43 $\cdot$ L13 $\cdot$ L61 $\cdot$ N53 $\cdot$ N83

\section{Introduction}

Despite Adam Smith's much-quoted 1776 dictum that "People of the same trade seldom meet together ...but the conversation ends in a conspiracy against the public, or in some contrivance to raise prices," it is often held that cartels did not

We thank the Organization and Strategy Department at Maastricht University and the Department of Economics, Purdue University for financial support, and thank anonymous referees, and the Editor for useful comments. We thank the Purdue University Interlibrary Loan department and Sonya Hymer for research assistance. Responsibility for errors is our own.

Stephen Martin

smartin@purdue.edu

Andrea Günster

andrea.guenster@ip.gess.ethz.ch

1 ETH Zurich, Zurich, Switzerland

2 Purdue University, Lafayette, IN, USA 
emerge as enduring features of the economic landscape until the last part of the nineteenth century.

In this view, cartels as a form of private market organization can be traced to the industrial revolution: canals and railroads widened geographic markets and exposed firms to internecine competition; periodic depressions exposed the owners of firms that had financed substantial sunk investments to the risk of bankruptcy. The business reaction was to band together to avoid annihilation; cartels were (Kleinwächter 1883, p. 143) "children of bad times."

In this paper, we advance two claims based on a study of the fifteenth-century European market for an intermediate good, alum, that was an essential input for the lucrative textile sector. The renaissance-era alum market was home to a series of anticompetitive arrangements. One of these, a 1470 cartel agreement between the Pope and the King of Naples, was reduced to written form, and its terms reveal much about the internal organization of the cartel.

The first claim is that these pre-industrial revolution, pre-business-cycle cartels can be explained by a motivation that is present in good times as well as bad (again paraphrasing Adam Smith): "to get the highest price that can profitably be got."

And this leads to the second claim. The 1470 cartel agreement was intended to last 25 years. It may have collapsed after little more than 2 years. This possibility has been interpreted as an indication of the failure of a Papal plan to monopolize the European alum market. Yet the European alum market generated an immense amount of economic profit in the period between the discovery of alum deposits in the Papal States in 1462 and the development of methods to produce alum by artificial means in 1788 .

We suggest that far from being a sign of the failure to exercise monopoly power in the alum market, the breakdown, or shunting aside, of the Rome-Naples cartel is more appropriately viewed as part of the process of the Papal States learning the limit price: learning what was "the highest price that could be got" without inducing entry.

The paper is organized as follows. In Sect. 2 we document views that cartels are postindustrial-revolution phenomena. The first part of Sect. 3 deals with the alum market in the period before the fall of Constantinople in 1453 and the subsequent disruption of the alum supplies to Europe. The second part covers 1453-1470: the period that leads up to the Rome-Naples cartel agreement. Section 4 discusses the cartel agreement. Section 5 deals with a final period that saw the consolidation of the Papal alum monopoly, under the management of the gifted merchant-banker Agostino Chigi, within limits that were imposed by entry costs and consumer switching costs. Section 6 concludes. The "Appendix" contains a translation of the 1470 cartel agreement.

\section{Cartels as a Post-industrial Revolution Phenomenon}

Freedeman (1988, p. 462) links the rise of cartels to the Great Depression of $1873^{1}$ :

\footnotetext{
${ }^{1}$ For a general discussion of the 1873 depression, see Rosenberg (1943).
} 
The depression of 1873 marked the beginning of the modern cartel movement in Europe. Although cartels existed before 1873, it was only in the four decades preceding the outbreak of the First World War that they developed into a significant force in the economy. ...Falling world prices for agricultural and industrial products from 1873 to 1896 sparked a search for ways to escape the rigors of competition and maintain prices at a remunerative level.

For Deák (1936, p. 415), cartels were not an important feature of the French economic landscape before 1873 because cartels were not needed either to exercise market power or avoid bankruptcy: "The steam engine and the impetus to large scale, standardized factory production, had barely begun to appear. There were, as yet, no railroads, which later broke down the localization of trade and enabled producers to penetrate distant markets."2

Allen (1968, pp. 51-52; see also Allen 1954, p. 88) makes very much the same kind of argument for Great Britain: "In the days when most markets were local, the force of competition was necessarily weak. Improvements in transport, by the construction first of canals and then of railways, greatly enlarged the area of competition and exposed suppliers who hitherto enjoyed a local monopoly to rivalry from outside."

Gerber (1998, p. 26) writes that, "The crises of the 1870s had capsized many firms, and continuing pressure on prices and profits kept this threat very much alive. This induced many firms to cooperate for the purpose of maintaining prices. As a result, cartels expanded rapidly from about 1880, flourishing most prominently in Germany and Austria." 3

To be sure, the presence of cartels before 1873 is acknowledged in the literature. A coal cartel operated in England, with intermittent success, from 1771 (Tan 2009). Maschke (1968, p. 103) lists five German cartels in the years 1820-1829, 13 in the 1850 s, eight or nine in the 1860s. Deák (1936), who reviews early French antitrust decisions, mentions an 1828 case of a local crockery cartel that established a joint sales agency, an 1850 case of collusive predation in the transportation sector, and other instances of collusion in the mid-nineteenth century. ${ }^{4}$ But such cartels are generally viewed as early exemplars of the post-industrial-revolution type of defensive cartel, arising where the market-expansion effect of the industrial revolution had its earliest impacts.

\footnotetext{
2 Morsel (1976, p. 118) writes, "Cartels [ententes] were born in France in 1876; they spread after 1890, and from 1914 many branches of industry were involved on the national and international plane."

3 See similarly Voight (1962, p. 170): "Forerunners of cartels existed in Germany in earlier centuries. The modern cartel, however, is a product of liberalism, a reaction of enterprisers to the opportunities inherent in a free market economy, but also a safeguard against the adverse effects of business cycles inherent in the process of industrial growth."

4 Schröter (1996, p. 131) writes that, "The oldest French industrial agreement we know of is the Marseille cartel on soda, concluded in 1838," and gives examples of Belgian cartels from the 1850s onward. Rénaud (1960) discusses the 1830-1857 French crystal cartel, which also involved a joint sales agency. Riesenfeld (1960) mentions an 1836 instance of collusive predation in the French stagecoach industry, but gives no details.
} 


\title{
3 The European Alum Market in the Middle Ages
}

\subsection{Mining and Manufacture}

Delumeau (1962, p. 72) estimates that between 1462 and 1796 some 17 million tons of alunite, from which alum was extracted, were taken from the Papal alum mines at Tolfa. ${ }^{5}$ Techniques for the production of alum from alunite, ${ }^{6}$ which changed little over this period, involved four stages that served to remove impurities and render the substance into commercializable form. The four stages were calcination (roasting in a kiln for 10 or more hours); maceration (sprinkling heaps of calcinated rock with water once or twice a day for 40 days, causing it to separate); lessivage (boiling the resulting material to separate impurities); and crystallization. ${ }^{7}$

\subsection{Role in Commerce}

In this age before the development of chemistry, alum was an essential input for a range of highly profitable industries (Singer 1948, p. xvii):

\begin{abstract}
Alum owes its commercial, industrial and historic importance chiefly to its affinity for fibres of wool, silk, cotton and linen. These, or fabrics woven from them, when impregnated with alum, will absorb certain natural dyestuffs more freely and develop colours that are brighter and more fast than if not so treated. Alum is thus a fixer of dyes, or mordant. This property has been familiar to craftsmen for perhaps 4000 years. For at least 2000 years, hides have been known to become more durable and more supple when impregnated with alum. For 15,000 years or so, it has been recognised that parchment when alumed becomes more durable, better knit and more receptive of ink or pigments. For some 600 years the same has been known of paper, the fibres of which adhere better when alum is used with the size.
\end{abstract}

This meant that (von der Ropp 1901, p. 121) "In the Middle Ages alum was among the most valuable traded goods...". 8

\subsection{Before the Fall of Constantinople}

In fifteenth-century Europe, the Papal State was a temporal power that directly controlled much of the center of the Italian peninsula. To its south lay the Kingdom

\footnotetext{
${ }_{5}$ According to Hoover and Hoover (1912, p. 565, fn. 12), the commercial product was "the double basic potassium alum."

${ }^{6}$ Delumeau (1962, pp. 59-74) reviews several descriptions of the production of alum at Tolfa. The most useful are Agricola (1556, pp. 568-571 in the Hoover and Hoover 1912 edition) and a 1765 report of Fougeroux de Bondaroy, read before the l'Academie Royale des Sciences, from which Delumeau gives four pages of text and reproduces four plates illustrating the Tolfa alum works.

${ }^{7}$ A figure on page 571 of Agricola (http://www.gutenberg.org/files/38015/38015-h/images/fig571.jpg) illustrates the four stages.

8 Along the same lines, see Strieder (1925/1971, p. 168), Singer (1948), Heers (1954, p. 31) and de Roover (1966, p. 157).
} 
of Naples, which for much of our period of interest was ruled by the dynasty of the Kingdom of Aragon. In northern Europe, textile-producing Flanders was a major market for alum. ${ }^{9}$ England, France, and Venice were other important regional markets. Venice consumed alum in its own right and exported it to Germany and other markets in Northern Europe.

Europe's supply of alum came from the Eastern edge of the Byzantine Empire, and was under almost continuous control of Genovese merchants from 1275 until $1455 .^{10}$ (See Table 1 for the timeline 1275-1470). Lower-quality alum deposits were known in Europe, but they were not commercially viable alternatives to the Byzantine product.

Toward the end of this period, rivalry between two Genovese merchant groups flooded European markets with alum and caused prices to fall. In 1449, the Genovese alum merchants succeeded in reversing the price decline with a cartel contract, intended to last for 6 years, that united control of extraction, transport, and sale (Heers 1954, pp. 39-40; Carlo 1984, pp. 26, 28).

\subsection{After the Fall}

But Constantinople fell to the Turks in 1453, 2 years before the 6-year cartel agreement was to end. The considerable stocks of alum that had been accumulated by the Genovese cartel kept the European market supplied for some time. But by 1458 , those stocks were exhausted and the price of alum rose to levels that disrupted industries for which alum was an input: in particular the textile industry. By 1461, the Genovese lost control of what had become the Turkish alum deposits (Heers 1954, p. 51).

1458 was a momentous year for the alum market for other reasons. It saw the election of a new Pope, Pius II, and the crowning of a new King, Ferdinand I, of the Kingdom of Naples, which was the Papal States' immediate neighbor to the south.

The alum shortage and consequent price increase encouraged exploration for alternative sources, and in short order lesser-quality alum deposits of ambiguous amounts were discovered or rediscovered within Europe, at Agnano (a short distance from Naples), Volterra (which came into the orbit of Florence), in Spain, and on the island of Ischia, which was also part of the Kingdom of Naples.

But the most noteworthy find, in 1462, was the rich alum deposits at Tolfa, in the Papal States, near Civitavecchia, the port city of Rome. ${ }^{11}$ For the Pope, the discovery (and subsequent exploitation) was doubly valuable: it deprived the Ottoman Empire of the substantial income that the Empire received from Europe for

\footnotetext{
9 Following the death of Charles the Bold of Burgundy in 1477, Flanders passed into the hands of the Habsburgs. See Mallett (1998), Ryder (1998), and Schnerb (1998).

10 There was a brief interruption in Genovese domination of the European alum trade from 1340-1346. On the Genovese role in the alum trade, see Heers (1954).

11 Accounts of the discovery of alum at Tolfa are based, directly or indirectly, on Pius II's autobiographical Commentaries (1962, pp. 233-234). May 1462 is the most likely time of the discovery, but other dates have been suggested. See Barbieri (1940, p. 16, fn. 2) for discussion.
} 
Table 1 European alum market timeline, 1275-1470

\begin{tabular}{|c|c|c|}
\hline Year & Government & The Alum Market \\
\hline 1275 & & $\begin{array}{l}\text { Genoa merchants get monopoly concession for } \\
\text { Turkish alum mines }\end{array}$ \\
\hline 1449 & & $\begin{array}{l}\text { Excess supply; low prices; Genovese cartel, price } \\
\text { recovery }\end{array}$ \\
\hline 1453 & Fall of Constantinople & \\
\hline 1458 & $\begin{array}{l}\text { Ferdinand I becomes King of } \\
\text { Naples; Pius II elected Pope }\end{array}$ & $\begin{array}{l}\text { European stocks of alum exhausted; } 1458-1462, \\
\text { alum deposits found at Volterra (Tuscany), Agnano } \\
\text { (Kingdom of Naples) }\end{array}$ \\
\hline 1462 & $\begin{array}{l}\text { First payment from Tolfa mines } \\
\text { saves Papal States from } \\
\text { insolvency }\end{array}$ & $\begin{array}{l}\text { Alum discovered Mazarron (Spain), Tolfa (Papal } \\
\text { States); a payment by the Medici bank on behalf of } \\
\text { the Church to feudal rulers of Tolfa assures Church } \\
\text { control of the deposits; inefficient early exploitation } \\
\text { of Tolfa alum. (Sept) Apostolic Camera sells } \approx 333 \\
\text { tons alum to Genovese group; (Nov) sells identical } \\
\text { amount to another Genovese group; (1 Nov) grants } \\
\text { a 3-year contract to farm (but not market) Tolfa } \\
\text { alum }\end{array}$ \\
\hline 1463 & $\begin{array}{l}\text { Pius II dedicates funds from alum } \\
\text { to support a crusade }\end{array}$ & $\begin{array}{l}\text { Medici interests buy } \approx 1250 \text { tons alum (April), } 1000 \\
\text { tons (June) }\end{array}$ \\
\hline $1464-1465$ & & $\begin{array}{l}\text { Alum (re)discovered on island of Ischia (Kingdom of } \\
\text { Naples) }\end{array}$ \\
\hline 1464 & Paul II elected Pope & \\
\hline 1465 & & $\begin{array}{l}\text { Contract granted to work Agnano mines; 9-year } \\
\text { contract to farm Tolfa mines }\end{array}$ \\
\hline 1466 & & $\begin{array}{l}\text { Medici group gets 9-year contract to market Tolfa } \\
\text { alum }\end{array}$ \\
\hline 1467 & & $\begin{array}{l}\text { High prices of Papal alum; England \& Flanders allow } \\
\text { import of Turkish alum }\end{array}$ \\
\hline 1468 & & $\begin{array}{l}\text { Treaty establishes 12-year monopoly of Papal alum in } \\
\text { Burgundy \& Flanders; price not to be higher than } \\
\text { that in neighboring regions }\end{array}$ \\
\hline 1470 & & $\begin{array}{l}\text { Cartel agreement between Papal States and the } \\
\text { Kingdom of Naples; Rome-Venice alum agreement } \\
\text { that provides for payment to Kingdom of Naples } \\
\text { according to cartel agreement }\end{array}$ \\
\hline
\end{tabular}

its supply of alum and (because Tolfa lay within the Papal States), the discovery also transferred that income to the Papacy. ${ }^{12}$

Papal control of the new-found deposits was secured by a payment from a Medici bank to the local feudal lords. This was perhaps the first of many side-payments associated with Tolfa alum.

\footnotetext{
12 Ryder (1998, p. 580) writes, "All this warfare, however, had cost Pius great sums at the same time that he was endeavouring ...to lead Europe by example into a crusade. There came providentially to his rescue the rich alum deposits discovered in 1461 north-west of Rome at Tolfa, profits from which in time boosted papal revenues by some $20 \%$."
} 
In 1462, the Apostolic Camera, which managed Church finances, granted a group that was associated with the discoverer of the Tolfa alum a 3-year contract to "farm" (that is, mine) the Tolfa deposits, but reserved marketing for itself. At first, the Camera sold the Tolfa alum to commercial groups for resale, and soon developed the practice of granting two contracts: one to work the mines, the other to market the alum that was extracted from the mines. The first such marketing contract, which was granted in 1466 to a group that was associated with the Medici interests, was to last 9 years. $^{13}$

In 1463, Pius II dedicated receipts from contracts to market the Tolfa alum mines to support a new crusade, and in furtherance of this project, prohibited the import of Turkish alum into Europe, on pain of excommunication. These policies were continued by his successor, Paul II, who ascended to the Papacy in 1464. Income from the Tolfa mines was maintained separately from general Church accounts in La Crociata, "the Crusade," which was an office established specifically for that purpose.

Over the remainder of the fifteenth century, Roman alum came to grips with the constraints imposed by the marketplace: that a high price will invite entry and encourage users to seek alternative sources of supply; and that if entry cannot be blocked, the high price will not be realized.

The Medicis initially set the price of Tolfa alum so high that England and Flanders allowed the import of Turkish alum, notwithstanding the threat of excommunication. In 1468, a 12-year treaty was negotiated with the Duke of Burgundy that guaranteed to Rome the exclusive right to supply alum in Burgundy and Flanders, subject to the condition that the price not exceed the price in neighboring regions. ${ }^{14}$ Thus the treaty protected the merchants to which it applied against the possibility that nearby rivals would be able to buy an essential input at a lower price, while raising the cost to Rome of cutting price in neighboring regions.

\section{The Cartel Agreement}

\subsection{Terms}

Of the European alum deposits that had been discovered or rediscovered after the fall of Constantinople, it was those located in the Kingdom of Naples, at Agnano and on the island of Ischia, that most seriously troubled Roman plans.

\footnotetext{
13 Delumeau (1962) reports the terms of contracts before 1500 in Chapter 2, and the terms of contracts from 1501 to 1796 in Chapter 3, Table I. There are gaps in the records. Those who received contracts to farm Tolfa alum often made loans on advantageous terms to the Popes who awarded the contracts; see footnote 24. Such transfers would not appear in the formal contract, but were part of the cost of doing business. Contracts specified a payment to the Church per unit sold. It happened that the price that the contractee could get was not sufficient to cover the payment, and, ex post, the Apostolic Camera agreed to accept a lower payment than that specified in the contract.

14 In modern antitrust parlance, such arrangements would be described as a "most favored customer" agreement. There were fruitless efforts to negotiate a similar treaty with England.
} 
The mines at Ischia were under the direct control of the Kingdom of Naples. ${ }^{15}$ On June 11, 1470, the King of Naples and Pope Paul II formalized a cartel agreement to combat low prices, stating in the preamble ${ }^{16}$ :

[T] he price of the [Tolfa] alum ... was being greatly diminished by the fact that alum from the Ischian mine ... was also being supplied to those same parts of the world to which the alum of the Cross had been supplied or, more frequently, which bordered on those places, with the result that, because of the combined quantity and abundance, the price of either [commodity] was being restricted or was dropping, and ... was providing very little profit.

The cartel was to last for 25 years. For the life of the agreement, half of each delivery of alum was to be supplied by each party; each would receive half the proceeds, and each would be responsible for its own costs. Sales were to be at the agreed price, and if there were sales below that price, the party responsible would make up the losses of the other party. Sales were to be for cash, not barter, and credit was not to be given for more than a year. Each party was to have a Commissioner at the mines of the other, with keys to warehouses and the right to keep track of production and shipments.

Special arrangements were made for Tolfa alum already in warehouses in Bruges and Venice. These areas would be supplied with Tolfa alum until supplies were run down, but one-sixth of the profit from such sales would go to the King of Naples. ${ }^{17}$ Further, and consistent with the 1468 exclusive supply agreement that was noted in Sect. 3.4, a maximum price was specified for alum that was delivered to regions that were controlled by the Duke of Burgundy.

If one party was unable to supply its half of a shipment, the other party could make up the difference, with a corresponding increase in its share of the profit. Delumeau (1962, p. 25) speculates that the Pope anticipated an inability of the Ischia mines to supply its half of shipments, and see in this an explanation for the Pope's willingness to accept a contract that was generally favorable to Naples. ${ }^{18}$

Violations of the agreement were to carry a fine of 50,000 ducats, which de Roover (1946, p. 169) describes as "enormous." (We know of no evidence that fines were ever assessed). Payment of the fine would not excuse the offending party from its obligations under the contract.

The terms of the cartel agreement are entirely consistent with the modern analysis of noncooperative collusion. The mutual exchange of commissioners

\footnotetext{
15 The mines at Agnano were privately owned. Alfonso II was King of Naples for 13 months from January 25, 1494, and granted a Medici group a contract to work the Agnano mines. While this contract was in effect, Medici interests controlled both the Tolfa and the Agnano mines. Alfonso's son and successor, Ferdinand II, restored the Agnano mines to their previous owner.

16 Two copies of the agreement are known. Theiner (1862) reproduces the copy that is in the Vatican archives, which has the preamble and general terms in church Latin and details of the cartel in antique Italian. An English translation is in the "Appendix" to this paper. Strieder (1925, p. 172, fn. 2) notes the existence of a handwritten copy of the cartel agreement in the Archives of the State of Rome.

17 A Rome-Venice treaty concluded later in 1470 provided for such payments.

18 Zippel (1907, pp. 36-37) and Delumeau alternatively suggest that the imminent threat of the invasion of the Italian peninsula by the Ottoman Empire (a threat that materialized in 1480) may be sufficient explanation for the nature of the agreement.
} 
promotes the rapid detection of competitive behavior. ${ }^{19}$ Ruling out barter sales and strictly limiting credit terms eliminate subtle ways to shade the cartel price. The fine for violations served to reduce the expected profitability of defection, which is another key to cartel stability.

The contract also contains provisions that were designed to raise the cost of importing alum into the European market. One such provision incorporated a policy that had already been adopted by the Church, the penalty of excommunication for the import of Turkish alum into Christendom. Piracy was permitted against ships that transported alum, with no mercy to be shown to prisoners. Alum taken as plunder could be sold to the cartel for half the price at which it would have sold at its destination market. Those in possession of confiscated Turkish alum were at liberty not to sell it to the cartel, in which case they were free to sell it at the end of the 25-year term of the cartel agreement.

\subsection{When did the cartel agreement end?}

The archives of the Apostolic Camera record the expenses of the papal commissioner at Ischia; the last such records are for October 1472 (Zippel 1907 , p. 37, fn. 2). Thus the 25-year cartel agreement, entered into by Paul II, may have ended little more than 2 years later, under his successor Sixtus IV. (See Table 2 for the timeline 1471-1495).

By the terms of the cartel agreement, if the Ischia deposits had been worked out, the Tolfa mines could have supplied all demand for alum, and kept all the resulting profit. The Ischia deposits were certainly of lesser quality than those at Tolfa. But the Ischia mines had not been exhausted in a physical sense in 1472: contracts to work the Ischia mines were granted in 1483 (Croce 1949, pp. 37-39) and again in 1596 (Zippel 1907, p. 496, fn. 1; Delumeau 1962, p. 28).

Relations between Pius II and Ferdinand I had been strained. ${ }^{20}$ Conflicting interests arising out of the alum market may have been one aspect of this general tension. Sixtus IV came to a weakened Papacy, and made considerable effort, including matrimonial alliances and territorial and fiscal concessions, to calm the waters with Sicily (Pastor, pp. 244-246).

Barbieri (1940, p. 28, fn. 29) observes that there is no affirmative evidence that the cartel agreement was abrogated before its projected 25-year term had run its course. Mignanti (1936) writes that in 1497, "after the 1470 agreement expired," the Apostolic Camera awarded Agostino Chigi a contract to farm the Tolfa mines. ${ }^{21}$ Mignanti believed that the 1470 agreement had been carried to its 25 -year term.

\footnotetext{
19 "Rapidity" must of course be taken in the context of the times. Singer (1948, p. 149) remarks on the speed of a letter that went from Florence to Bruges in less than 3 weeks.

20 Pastor (1949, p. 152) writes that "The complicated relations which existed between Naples and the Apostolic See made it possible for the King to keep the Pope in perpetual alarm, by constantly making fresh demands. The real ground of [the King's] hostility was the jealousy with which he viewed the consolidation of the Papal power in the States of the Church, and accordingly he harassed the Pope in every way that he could."

21 Other sources (Mantenovesi 1937, p. 111; Barbieri 1940, p. 110; Delumeau 1962, p. 97) indicate that the contract was awarded in 1500 .
} 
Table 2 European alum market timeline, 1471-1500

\begin{tabular}{|c|c|c|}
\hline Year & Government & The alum market \\
\hline 1471 & Sixtus IV elected Pope & $\begin{array}{l}\text { Medici group gets 4-year renewable contract to } \\
\text { market Tolfa alum; Genovese vessels carry } \\
\text { Naples alum to the Netherlands, in violation of } \\
1470 \text { cartel agreement }\end{array}$ \\
\hline 1472 & & $\begin{array}{l}\text { Much effort by new Pope to restore good } \\
\text { relations with Naples; Rome-Naples cartel } \\
\text { dissolved (?); Pope an ally of Fiorentine } \\
\text { (Medici) conquest of Volterra and control of } \\
\text { Volterra alum deposits }\end{array}$ \\
\hline 1474 & & $\begin{array}{l}\text { Turkish alum imports continue, excess supply, } \\
\text { price decline }\end{array}$ \\
\hline 1476 & & $\begin{array}{l}\text { Sixtus IV grants Pazzi group 10-year concession } \\
\text { to market Tolfa alum }\end{array}$ \\
\hline 1477 & Death of Charles the Bold, Duke of Burgundy & \\
\hline 1478 & $\begin{array}{l}\text { Pazzi Conspiracy (with involvement of Sixtus } \\
\text { IV); assassinaton of Giuliano de' Medici; } \\
\text { attempted assassination of Lorenzo de' } \\
\text { Medici }\end{array}$ & $\begin{array}{l}\text { Pazzi Tolfa concession terminated; Genoa group } \\
\text { gets } 10 \text {-year concession }\end{array}$ \\
\hline 1479 & & Pope confiscates Tolfa alum shipped by Medicis \\
\hline 1483 & & $\begin{array}{l}\text { Kingdom of Naples grants contract to work } \\
\text { Ischia alum mines; Venetian ships sail to } \\
\text { Turkey to buy Turkish alum }\end{array}$ \\
\hline 1484 & Innocent VIII elected Pope & \\
\hline 1488 & & Medici group gets contract to market Tolfa alum \\
\hline 1492 & $\begin{array}{l}\text { Death of Lorenzo de' Medici; Alexander VI } \\
\text { elected Pope }\end{array}$ & \\
\hline 1494 & Alfonso II becomes King of Naples & $\begin{array}{l}\text { Medici group gets contract to work Agnano } \\
\text { (Kingdom of Naples) alum mines }\end{array}$ \\
\hline 1495 & Ferdinand II becomes King of Naples & $\begin{array}{l}\text { Agnano mines restored to previous owner; for } \\
13 \text { years, Chigi pays so mines will not be } \\
\text { worked; at the end of the cartel agreement (?), } \\
\text { Naples alum becomes potential competitor for } \\
\text { Tolfa alum }\end{array}$ \\
\hline
\end{tabular}

According to the Associazione Bancaria Italiana (1970, p. 303), "After the expiration of the cartel, the Neapolitan mines were returned by Ferdinand II to the poet Iacobo Sannazzaro, who with a notable number of workers managed to increase their exploitation." It was the Agnano mines that were returned to Sannazzaro, on 8 February 1495. This too implies that the cartel agreement remained in effect for its intended 25 years, and also that the Agnano mines may have been a greater threat than the Ischia mines to the profitable marketing of Tolfa alum.

There is no definitive evidence on the duration of the 1470 alum cartel. Whether it was in effect for 2 or 25 years, subsequent developments in the European alum market suggest that the managers of the Roman alum deposits learned how to exercise market power by other means. 


\subsection{Relational Contracts in a Machiavellian Age}

Given the relative bargaining positions of Rome and Naples at the start of Sixtus' papacy, if the 1470 cartel agreement ceased to bind, it seems likely that the change was part of a broader adjustment to a new equilibrium that served the interests of Ferdinand I, King of Naples.

The ending of the 1470 cartel agreement after 2 years would not have been unusual, nor, if it ended, can it be taken for granted that its end was the result of factors arising in the alum market. The 1470 cartel agreement was an international treaty, concluded at a time when sovereigns made and unmade treaties to suit the needs of the moment. In the last third of the fifteenth century, the dissolving of contracts before their time was the rule, not the exception.

As noted above, in 1466, under Pius II, Medici interests received a 9-year contract to market the Tolfa alum. The Pope reserved the right to end the contract after 30 months. The Medicis received a 4-year renewable contract from Pius II in April 1471.

In 1472, the new Pope, Sixtus IV, supported the conquest of Volterra by Florence (that is, by the Medicis). Before being shut down, the Volterra alum mines as well as the Tolfa alum mines were under Medici control.

Allegiances shifted, and in 1476 Sixtus IV granted a 10-year concession to market the Tolfa alum to a group that was associated with the Pazzis, who also were from Florence and rivals of the Medicis. In 1478 the Pazzi conspiracy resulted in the wounding of Lorenzo de' Medici and the assassination of his brother. The Pope had supported a change of government in Florence "as long as death doesn't come into it" (Martines 2003, p. 158).

After the failed coup, "to remove any appearance of complicity in the plot," (Zippel 1907, pp. 412-413) the Pope ended the Pazzi alum contract and awarded a new 10-year concession to a group from Genoa. The 10-year Pazzi contract thus ended after 2 years. The Pope also confiscated all Tolfa alum that had been shipped by the Medicis. ${ }^{22}$ In 1488, under Sixtus' successor, the Medicis again received a contract to farm the Tolfa alum. ${ }^{23}$

\section{Learning to Exploit the Alum Market}

\subsection{Agostino Chigi}

On December 24, 1500, a group that was associated with the Sienese banker Agostino Chigi obtained a 12-year concession to farm the Tolfa alum mines. ${ }^{24}$ (See

\footnotetext{
22 Troops from the Papal States and the Kingdom of Naples invaded the territory of the Republic of Florence. In a whirlwind of shifting alliances, in December 1479, Lorenzo made a secret trip to Naples and secured a peace treaty with Ferdinand I.

23 With the death of Lorenzo de' Medici in 1492, the central role of Medici interests in the European alum market faded.

24 Gilbert (1980, p. 72) writes that, “Agostino was aware that in his application for this lease he needed the support of [another group of Siennese bankers]. By giving them a share in the profits of the Tolfa
} 
Table 3 European alum market timeline, 1500-1520

\begin{tabular}{|c|c|c|}
\hline Year & Government & The alum market \\
\hline 1500 & & Chigi group gets 12 -year contract to work Tolfa mines \\
\hline 1501 & & $\begin{array}{l}\text { Chigi group gets Agnano concession (owner agrees to limit } \\
\text { output and sell only to Chigi) }\end{array}$ \\
\hline 1503 & Julius II elected Pope & \\
\hline 1504 & & $\begin{array}{l}\text { Philip the Fair authorizes import of Turkish alum into Flanders; } \\
\text { price falls in half }\end{array}$ \\
\hline 1505 & & $\begin{array}{l}\text { Flanders merchants ship Turkish alum to England, reship (some } \\
\text { of) it to Flanders, still able to undersell Roman alum }\end{array}$ \\
\hline $\begin{array}{l}1506 \text { or } \\
1507\end{array}$ & & $\begin{array}{l}\text { Rome-England agreement: England to prohibit Turkish alum, } \\
\text { purchase minimum quantity; Rome agrees to maximum price } \\
\text { of Tolfa alum }\end{array}$ \\
\hline 1507 & & France sets high tariffs on imported alum \\
\hline 1508 & & $\begin{array}{l}\text { Tolfa alum gets } 2 \text {-year monopoly on sales in Flanders, subject to } \\
\text { a maximum price }\end{array}$ \\
\hline 1511 & & $\begin{array}{l}\text { Combination of surreptitious loan to Venice, grant of alum } \\
\text { monopoly to Chigi by Venice }\end{array}$ \\
\hline 1513 & $\begin{array}{l}\text { Leo X (Giovanni de' } \\
\text { Medici) elected Pope }\end{array}$ & Chigi group concession for Tolfa alum renewed \\
\hline 1520 & & Death of Agostino Chigi \\
\hline
\end{tabular}

Table 3 for the timeline 1500-1520). With this contract, the two-contract system previously used by the Apostolic Camera was abandoned. Chigi's contract combined mining and marketing of the Tolfa alum (Barbieri 1940, p. 112). Chigi stabilized the European alum market on a number of fronts.

He organized the production of the Tolfa alum mines for greater efficiency, locating and exploiting the richest deposits (Associazione Bancaria Italiana 1970, p. 312). In 1508, he arranged a 50-year lease for the port city Porto Ercole, and made substantial investments to improve it for shipping alum.

Chigi also proceeded to take charge of other sources of alum within Europe. He reached an agreement with the owner of the Agnano mines to limit their output, which would be sold only to Chigi: a side payment to get cooperation. ${ }^{25}$ Within a year of getting the Tolfa contract in 1501 (Rowland 1986, pp. 677-678) "[Chigi] had also bought rights to most of the other alum fields in Italy, and what he did not lease outright by 1502 he controlled through ...political connections.... In these other areas he closed down production, thereby concentrating the industry at Tolfa."

For marketing, Chigi granted exclusive territories to what amounted to subsidiary franchisees (Gilbert 1980, p. 78): "Chigi divided Europe into different regions; in

Footnote 24 continued

mines and paying Pope Alexander VI an advance of 7000 ducats on the grazing tax and an advance of 20,000 ducats on the Tolfa revenue, he could acquire the lease to the mines." Similarly, Pope Leo X renewed the Tolfa concession following loans of 75,000 and 12,000 gold ducats from the Chigi bank on the occasion of his assuming the Papacy (Franchini 1950, p. 160).

25 There were similar side-payments in 1539 and 1582 (Pipino 2009, p. 32). 
each of them he had either an agent who sold alum on Chigi's behalf, or he made a contract with a merchant living abroad who received the right to sell alum in a strictly limited area and was to share the proceeds with Chigi."

Chigi thus established an infrastructure to distribute the European supply of alum, which he effectively controlled. It remained to work out the limits within which he could profitably exercise this control.

Chigi initially set the price of alum above the limit price. The results were what would be expected based on the simple limit-price model: Turkish alum appeared in European markets.

Flemish and English textile merchants complained to their respective rulers. Philip the Fair, Duke of Burgundy, authorized the import of Turkish alum. Flanders merchants formally avoided the Papal interdict by bringing Turkish alum to England and transshipping some of it to Flanders. The price of Tolfa alum was high enough for this strategy to remain profitable. The price of alum in Flanders fell in half. In 1508, Chigi accepted an upper limit on the price of Tolfa alum in Flanders, and obtained a 2-year exclusive right to supply the Flanders market.

Henry VII of England used the threat of Turkish alum (Carlo 1984, pp. 36-37) "for the purpose of containing the price of the Roman [alum]." In 1506 or 1507, Rome guaranteed a maximum price and minimum quantity of alum in return for the exclusive right to supply the English market.

The Venetian market for alum was particularly lucrative, as Venice was alum's gateway to much of northern Europe. In 1511, a disguised loan to the Venice government enabled Chigi to get the exclusive right to supply the Venetian market (Gilbert 1980).

Mercantilist France imposed tariffs on Tolfa alum, and sought to develop its own alum supplies, largely without success. The tariffs were reduced for Normandy, where the textile industry was important, and Tolfa alum found its way into the French market (Zippel 1907, p. 304; Carlo 1984, p. 36).

\subsection{Exercising Market Power, Within the Limits Imposed by the Market}

The bulk of the literature interprets the early collapse (if such it was) of the NaplesRome alum cartel as evidence of the failure of the Papal scheme to monopolize the European alum market (Delumeau 1962, p. 54): ${ }^{26}$ "[T]he Tolfa mineral was subjected to ...the free play of supply and demand." In our view, this goes too far: The disappearance of the cartel is also consistent with Rome learning that it did not need a cartel to exercise market power. And the existence of higher-cost alternative supplies constrains market power, but does not eliminate it.

Two types of evidence suggest that Rome was able to extract substantial economic profit from the European alum market. One is the tremendous wealth that was accumulated by those associated with the Papal alum trade. At his death, Agostino Chigi was reputed to be the wealthiest private citizen in Europe. His

\footnotetext{
${ }^{26}$ For similar views, see Gottlob (1889, p. 300), Zippel (1907, p. 32), Nef (1941, p. 16), Singer (1948, p. 160), and de Roover (1966, p. 164, focusing on the Medici period).
} 
banking interests ranged far and wide, but their foundation was the Tolfa alum concession (Franchini 1950, pp. 159-160).

The Agnano mines were less rich than those at Tolfa. But they were remunerative enough to be the basis of a lawsuit by the heirs of Iacobo Sannazzaro, around the end of the fifteenth century, seeking to break the contract to farm the Agnano deposits, which they thought unjustly enriched the contractor (Pipino 2009, pp. 31-32).

Delumeau (1962, pp. 154-155) presents some estimates of Papal revenue from the European alum market. He judges it to have been much less than what Spain took from the New World in silver and gold, but still five times the gross annual revenue of the Papacy, and enough to build five churches on the scale of St. Peter's Cathedral.

The other evidence that Rome succeeded in exercising market power in the European alum market is the continuing efforts of Rome's customers to find other supplies within Europe. Rome had sought its own supplies to escape Turkish market power. Other European states reacted in the same way to Roman control of the European alum market. They succeeded, over time, and supplies outside Roman control developed in Spain, Germany, Bohemia, and England. The limit price, and Rome's revenue, fell with each successive discovery. But alum became a commodity only with the development of technology that enabled its production by artificial means in 1788 .

\section{Conclusion}

The "detailed provisions" of the 1470 contract "make it a full-fledged cartel agreement" (de Roover 1946, p. 169). Those provisions reveal an internal organization that was very much in line with what would be expected in light of the modern theory of noncooperative collusion. Whether the cartel was abandoned after little more than 2 years or served out its 25-year term, Tolfa alum was able to buy off (as with Agnano) or destroy (as with Volterra) potential competitors. In the early years after the discovery of alum at Tolfa, Rome assured itself of control of the supply of alum within Europe. Like other single suppliers, it was able to extract monopoly profit only within the limit imposed by the availability of alternative sources of supply. Over time, that limit became increasingly stringent, with the discovery and development of additional alum deposits within Europe.

One may suspect ${ }^{27}$ that local cartels have been widespread since the beginning of time, although difficult to document precisely because they were local. Events in the European alum market at the end of the fifteenth and start of the sixteenth century show that both collusion and strategic conduct by dominant firms to raise entry cost have a history that predates the industrial revolution. The analysis of the conditions that induce firms to collude and to try to deter entry remains a topic about which much can be said, and the study of larger historical cartels and dominant firms has much to yield in this regard.

\footnotetext{
27 As has been suggested by the editor.
} 


\section{Appendix}

\section{Preface}

The first and third portions of the agreement are written in Church Latin. The first section presents primarily political but also some economic motivations for the agreement ("the price of the ... alum ...was being greatly diminished ... because of the combined quantity and abundance, the price of ...was being restricted or was dropping, and ...providing very little profit). The first section also identifies diplomatic representatives involved in concluding the agreement.

The second section of the agreement is written in Medieval Italian. It outlines the mechanical details of the cartel.

The third section affirms the commitment of the signatories to honor the terms of the agreement, and outlines the payment to be made to the Apostolic Camera if the terms are breached.

\section{Text of the Agreement}

In the name of our Lord Jesus Christ, amen. In the 1470th year since [our Lord's] birth, in the third indiction [15-year cycle], on the 11th day of the month of June, in the sixth year of the Most Blessed Pontificate of our Lord Pope Paul II by divine providence. Let it be known by each and every person who shall see, or read or hear this present document, That since it is so, that our same Most Blessed Lord Paul who, not without heavy bitterness in his heart, even before he was appointed to the office of the apostleship through the favour of divine clemency, had to deplore the massacring of Christians, the ravaging of lands and fields, the plundering and burning and all the other damnations visited upon faithful followers of Christ, $\mathrm{O}$ Great Pain! which the most deplorable leader of the Turks had thus far brought about and has been doing so with greater fervour in [recent] days, and has also reduced kingdoms and widespread provinces to destruction and aggressively subjected the orthodox faith to his abominable power; [the Pope], lamenting over so heavy a loss to the Christian state with his fatherly affection, [seeing] these sins being committed, bore the wretched servitude of the faithful painfully, and piously felt pity for the calamities of the faithful, and frequently considered their sad misfortunes in inner meditation; being subsequently elevated to the highest pinnacle of the Pontificate by heavenly command, he wished, with consent from on high, to bring to fruition those things he had been considering in his heart, and to use every effort and means possible, whereby the most cruel attempts of the destroyer of the life-giving Cross might be repressed; and along with the other resources of the Roman [Catholic] Church itself, together with great sums of money and other property which he had willingly offered and contributed for so righteous a task (no small part of which he continuously offered in faith to those concerned with the efforts and condition of the faithful in these and other matters), he willingly devoted, set aside, granted and put to use each and every profit from alum and revenue from the old mine at Tulphis, which was established under the temporary 
dominion of the church, and which were to be given for the glory of [Christ] himself, and of the faith, and of the faithful, and for the work and benefit of the Holy Cross; and with ready heart he dedicated them to God Almighty; and to carry out this great endeavour in preserving and distributing that same commodity, he appointed the most Reverend fathers in [the name of] Christ and lords, the Bishops Bessarion of Sabina, William of Ostia and John of Porto, Cardinals of that same Holy Roman Church, to be considered as general commissaries; and when the same Bishop John of Porto meanwhile passed away into holy remembrance, in his place he proposed as successor the most Reverend father in [the name of] Christ and lord, Bishop Latinus of [Tuscula]: and lastly our Most Blessed Lord carefully considered that the price of the same alum being dedicated to the same holy task was being greatly diminished by the fact that alum from the Ischian mine, belonging to the most serene prince the lord Ferdinand, King of Sicily, was also being supplied to those same parts of the world to which the alum of the Cross had been supplied or, more frequently, which bordered on those places, with the result that, because of the combined quantity and abundance, the price of either [commodity] was being restricted or was dropping, and his appointed contribution for the Holy Cross was providing very little profit. The aforementioned most Serene Highness the King, realised this and approached his Holiness; then his Holiness freely gave his consent and approval, and for the common good, or more properly for the convenience and service of the Cross and states of the aforementioned [peoples], and he decreed, gave thanks and commanded that most Reverend lord Cardinals, as [named] above and undersigned, should arrange terms, agreements and accords in the fashion and form set out below. And so it is, that most Reverend lords, Cardinals Bessarion, William and Latinus, the aforementioned general commissaries for the Holy Cross, in the name of the Holy Cross itself, and most Reverend father in the [name of] Christ lord Mark, elder of St Mark's with divine compassion, Cardinal Bishop Vincentinus in the name of the apostolic Camera, in the presence of our same Most Holy lord, and in the presence of us the notaries and the undersigned witnesses, who were summoned especially for the matters mentioned below, were appointed personally for the one [reason]; and the notable lord Anelus Perocius, citizen of Naples, administrator and agent of the aforementioned most Serene Highness King Ferdinand, was in possession of a special mandate for the matters written below from his most Serene Highness King Ferdinand, written in the form of letters set out on parchment, and signed by the aforementioned most Serene Highness King Ferdinand by his own royal hand, which he then displayed as having been done; and this was seen and read by us the notaries; the contents of [the document] are included below, and it bore the appended great royal seal with silk ribbons of yellow and red; the same lord Anelus, with each of the two parties on bended knee before the feet of our same most blessed lord, also nevertheless urged greater caution concerning confirmation and ratification and [stated] that he would act and administer in such a way that the aforementioned most Serene Highness King Ferdinand will ratify, confirm and approve each and every thing to be promised by lord Anelus in his name and contained in this present document in its entirety in the following month of July in all things and for all matters, and through his authentic royal letters he will endorse our most blessed lord Pope, or the aforementioned most 
Reverend lords the Cardinals; certain sections containing within them agreements and accords concerning the association and the understanding which was to be carried out as set out were put forward in the presence of our aforementioned most blessed lord. Indeed the contents of this aforementioned royal mandate follow, and they are these:

FERDINAND by the grace of God King of Sicily, Jerusalem and Hungary [greets] each and every person who shall study the contents of this present [document], both now and in the future. In recent times we have had several dealings with our most holy and blessed lord Paul II, Pontifex Maximus, concerning his Holiness' alum traders and our own, for the mutual benefit and convenience of each party; and since the said dealings have been handled sufficiently by one side and the other and almost brought to full agreement, and it remains only to come to a final conclusion, it is necessary to select a trustworthy person who is informed in this matter, who can draw the said dealings or understandings to conclusion in our name: therefore I have placed my trust in Anellus Perocius, citizen of Naples, because of his trustworthiness, industriousness, diligence and integrity. He is a man who is outstanding, faithful and respected by us, whom we have long known of from experience through his ancestors, and who we do not doubt is fully informed of our mind in this matter. We have put our faith entirely in his trustworthiness and industriousness, that this will be carried out correctly and properly by him; and in the course of this present [document] we have appointed the same Anellus Perocius, a man faithful to us, and who is fully informed of our mind in this matter, as our special administrator and agent in the said association or understanding with the aforementioned most holy Pontiff and the apostolic Camera, or with any other persons in possession of a mandate and authority granted by his aforementioned Holiness and the apostolic Camera, under whatever name they are authorised, and whose names are used in the declarations, for discussing, drawing up and confirming [the agreement] using those clauses, timings and terms, penalties, oaths, declarations, conditions, manners and forms, whereby it would be plainly intelligible to the contracting parties; and in so far as we can do so, as if we been present, we can consider and deliberate the appropriate moves to make based on certain knowledge, so much the better and more effectively, and thus we can act, determine, arrange and consider, with no error in leadership, law or deed; and in the terms and in those things dependent on, arising from and connected with the terms, we grant to the same Anellus every type of power, facility and [authority] necessary and appropriate for implementing each and every term, and promise [to honour] whatever is negotiated, carried out and concluded by the said Anellus, [or whatever is] promised, put under obligation, sworn or agreed in our name, in good faith and without deceit, under royal word and trust and under the obligations, penalties and oaths, in the manners and fashions to be confirmed, established and concluded by the same Anellus; and we will observe them and cause them to be observed, will not contravene them, and will act directly or indirectly and with any special tones, conclusions, styles and forms necessary and appropriate as used in this present mandate that are sufficient for the terms, and from certain knowledge we will make them good and be determined to make them good. In the good faith of which we have ordered that this present [document] be marked with our appended great seal 
and that it shall prevail in judgment and beyond. Issued in the Castle in our City State of Naples on the first day of the month of June, in the one thousand four hundred and seventieth year of our Lord.

\section{KING FERDINAND}

Indeed this section has been reproduced just as it was submitted. Our most blessed lord, wishing it and its content to be made more familiar, ordered and commanded that through the Reverend Father in the [name of] Christ the lord Angellus, by the grace of God Bishop of Feltre, one of those presiding over the apostolic Camera, it be read in a loud and intelligible voice in the same place for the clear understanding of his Holiness and the aforementioned most Reverend Lord Cardinals and lord Anellus the administrator, whose names are above; however, he insists and commands that this present contract be agreed and that undoubtable good faith be applied to it, that it not be signed on the same day as a festival or ceremony of the Holy Spirit that may detract from it, and that attention be paid that this pious and most holy task be done with the invocation of the same holy spirit. The contents of these terms are included here below, word for word in the vernacular language, as follows.

\section{[Medieval Italian follows]}

In the name of His Holiness and His Majesty King Ferdinand of Sicila, the representatives agree that the society and union of all the alum works whether of His Holiness our Lord and the Apostolic Camera or His Majesty and similarly as regards alum production will be made according to pacts, means, and conventions indicated below, and that this society and union should last from the date of the present contract for the next 25 years. For the indicated period, the alum works of His Holiness our Lord and Apostolic Camera and those of his Majesty the King are to be understood as being a single body and soul.

During the indicated period, half of all the alum that will be consumed or transported by ship to diverse parts of the world for consumption or use shall come from the alum works of His Holiness our Lord and Apostolic Camera and the other half from the alum works of his Majesty the King. In addition when alum must be transported to any part of the world, half shall come from Civitavecchia from the works of Apostolic Camera and the other half from the alum works of the King.

This alum will be transported in every place in which it is ordered and shall be sold by two representatives, one of his Holiness our Lord and Apostolic Camera and the other of his Majesty the King and shall not be sold by others, and if sold by only one it is understood that half of the sale shall be for the account of our Lord and Apostolic Camera even if sold by the representative of his Majesty the King and vice versa and the other half for his Majesty the King, and this alum shall not be sold for more or less than what is estimated to be the price by the Apostolic Camera and his Majesty the King and if it happens that it is sold for a lower price he who made such a sale shall reimburse with his goods the missing profit. For all those who are charged with maintaining and selling said alum, the Apostolic Camera for its part and his Majesty the King for his part promise to compensate the other party without harm and similarly as regards other fraud or misdeeds committed by each of the deputies, and precisely each for his own part. 
The proceeds from the sale of the alum is to be divided in half, one for His Holiness and the other for his Majesty the King. For his half, each of the parties must separately pay the expense of working his own alum, transporting it and every other necessary expense and in the same way must keep separate accounts of receipts and expenses.

All the sales that are made must be made in cash by those charged with sales and not by barter, nor can one sell [on credit] for longer than about a year even if with suitable guarantees and not otherwise, and given the interim agreement between His Holiness Our Lord and the Apostolic Camera and the illustrious Lord Duke of Burgundy to maintain his provinces well furnished and the control of the alum, this cannot be sold at a price above 4 and a half pounds a shipment.

The aforementioned agreement must be observed in all its parts and in the same way the agreement made with certain merchants to wait to sell the alum transported up to today, in an amount of at most about 60,000 cantares to Bruges and about 30,000 cantares to Venice; in the places in which His Majesty the Lord King does not have alum, His Holiness above named Our Lord and the Apostolic Camera are pleased that in these places in which the sale of alum is established, His Majesty the Lord King shall share in one-sixth of the profit after subtracting the expenses that this alum costs the Apostolic Camera, and after the sale of this alum is finished, is obliged to transport half of the alum to these places and similarly sell half of it, as above, in the other places to which he will sail and from that time to sell half of it and the principles of this agreement are in force from the date the contract is entered into.

From this day forth neither of the parties can sell or have sold any quantity of alum from that made or to be made in the mines of the Apostolic Camera or of His Majesty the Lord King to specific individuals; but all the alum made and to be made during the above-named period must be stored and transported and sold on behalf of the company and by statement of each of the parties; in the realm near the alum mines of His Majesty the Lord King there will be a Commissioner in the name of the Apostolic Camera and at Civitavecchia by the alum mines of our Lord another in the name of His Majesty the Lord King and each of them is to hold keys to each of the storerooms and keep track of the alum that is produced and shipped. For these Commissioners and similarly for all the other Commissioners who may be sent to various parts of the world each shall supply provisions for his appointees as he thinks best and if one party wishes to insure himself for his half, he is authorized to do so and the expenses are those of the party who insures himself.

Every year there shall be a general prohibition of infidel alum and this alum and the ships in which it is transported are to be given as booty to those who have taken them and these cannot be obliged to pardon or have any mercy on their prisoners. And if they wish to give good saleable alum to the company for less than half what it would sell for in the places to which it was transported, the company must accept; if they do not wish to give it, it may be stored but not sold in the place where it comes into the possession of the appointees of the company until the end of the company itself; at the end of this time it can be sold.

And because it has been said above that each of the parties shall supply half the alum, in case one of the parties lacks alum or cannot make up to one half from the 
alum produced in his alum mines for whatever accident might occur, the other party can make up [the difference] and for this extra amount he supplies can take so much more [profit]. In the same way if in the transport or processing of alum or for whatever other reason the alum suffers damage or is not good or saleable so that there is a difference in the sales price, the resulting loss will be for the party of whom it is the alum.

\section{[Latin resumes]}

Indeed these terms, accords and agreements, were read by the aforementioned Reverend lord Father Angelus Bishop of Feltre, as said before, and immediately placed into the hands of us the aforementioned notaries on the orders of our same most blessed lord, also on the wishes of the aforementioned most Reverend Lord Cardinals and Lord Anellus. The aforementioned most Reverend Lord Cardinals, their respective names given above, and the aforementioned Lord Anellus, royal administrator and agent in turn (and) in the name of the aforementioned most Serene Highness King Ferdinand and on his behalf, as set out, in the presence of the most Holy Lord our Pope as above, heard these same terms, understood them and clearly thought them over, then accepted those same terms in their entirety, in so far as it concerned each of them, after they had been read out as set out. And they entered into and contracted the association between them, as described and named, on that occasion and with the agreements and terms expressed and included in the sections above, and they accepted and wished to be bound by those things entered into and contracted. And they and anyone among them, that is, the aforementioned most Reverend Lord Cardinals, in turn and in the name of the apostolic Camera and the Holy Cross respectively, and the aforementioned lord Anellus, royal administrator and agent in turn and in the name of the aforementioned most Serene Highness King Ferdinand and on his behalf, being the aforementioned parties, made their promises henceforth, that is, each party to the other; and with us the aforementioned notaries present as members of the public, they pledged and promised in turn and in the name of each and every person who is, shall be or may in some manner be involved in the future. And they-being the aforementioned most Reverend Lord Cardinals, their names being above, touching their hearts with their own hands in the manner of those in the stand, and the aforementioned lord Anellus the administrator-swore on God's Holy Gospels and in [God's] name, holding the sacred scriptures in their own hands, that for all time they would attend to and observe each and every thing contained in the Sections both jointly and singly, and not say or do for themselves or for any other person or persons anything to contravene them by reason, exception, title, manner or cause, by right or by deed, under the pledge and obligation of each and every blessing of the Holy Cross and of the apostolic Camera and of the aforementioned most Serene Highness King Ferdinand and of the summary power (sic) of the same most Serene Highness the King, for and under the penalty of fifty thousand gold florins or ducats, to be incurred and paid to the Camera without possibility of refund by the contravening party for each and every occasion where he may have contravened, and observance of each and every one of those things legally pledged and promised among those parties is to be applied to [each] aforementioned party. And whether such a penalty is incurred, enforced and paid or not, each and every thing promised is nevertheless fixed and retains steadfastness of great 
strength. Furthermore, [this applies] if the said parties, with the names given above, declare an exception to the said terms, [saying that they were] not accepted, not approved, and the association was not entered into in this way, in an act of wilful deceit, violence, intimidation, fraud; [or if they declare] an action or undue condition without reason and [that there is] an unjust(?) or shameful reason for the contract being observed in not this but some other way, or [if they use] the aid of either law, whereby it may be possible for those causing such division to help themselves or be protected in any way; then the general declaration shall not apply to [the party] administering special justice, unless there is a special [declaration] preceding it. All of these things were done and completed in the presence of our aforementioned most blessed lord, as set out, and our same most blessed lord gave his consent and assent in equal measure, and similarly gave it the authority of his sanctity and his resolve; yet he commanded that each and every one of the aforementioned things contained and described in the above Sections be observed by those parties without violation. Regarding and concerning each and every one of these things promised, the said parties, with the names given above, henceforth declared through us the undersigned notaries that these things be done one and all and that any document or documents be handed over.

These things were done in Rome in the apostolic palace at St Peter's in the Camera of the aforementioned most blessed lord the Pope in the year, indiction, day, month and Pontificate stated above, in the presence there of the most Reverend father in [the name of] Christ lord Oliverius, by divine pity of the title of Saints Peter and Marcellinus, elder of the Holy Roman Church and Cardinal of Naples, and in the presence of the Reverend fathers in [the name of] Christ lords Nicolas Archbishop of Siponto, and Ludovicus Bishop of Anglona, and the Magnificent soldier lord Laurencio de Iustinis of Citta di Castello, learned in both types of law, Senator of our good City, on bended knees, specially summoned and called upon for those things set out.

And I too, Johannes Geronnes, cleric of the diocese of Gerona, publisher by apostolic and Imperial authorisation and notary of the Apostolic Camera, was present when the said presentations, displays, contractual agreements, promises, obligations and authorisations, and each and every other thing contained in this present document, were done, said and made to happen, as set out, in the presence of our aforementioned most blessed lord the Pope. Also [present was] my colleague the undersigned honourable Hieronimus of Sassoferrato. And along with the aforenamed witnesses, and I saw and heard these things being done, and I took them down on paper, from which this present public document was written in good faith by the hand of my said colleague, which I then completed and turned into this format for publication, and signed it with my customary and usual signature and name and appended the seal of the said most Reverend lords the Commissaries of the Holy Cross and of the apostolic Camera, and having been summoned and called upon I underwrote it in the good faith and testimony of each and every one of those stated above.

And so too I, HIERONIMUS, formerly Johannis de Andisiis of Sassoferrato, cleric of Rimini, publisher by apostolic and Imperial authorisation etc. 


\section{References}

Agricola, G. (1556 [1912]). De Re Metallica. Herbert Clark Hoover and Lou Henry Hoover, translators. London: The Mining Magazine. http://www.gutenberg.org/files/38015/38015-h/38015-h.htm

Allen, G. C. (1954). Monopoly and competition in the United Kingdom. In E. H. Chamberlin (Ed.), Monopoly and competition and their regulation (pp. 88-109). London: MacMillan

Allen, G. C. (1968). Monopoly and restrictive practices. London: George Allen and Unwin.

Associazione Bancaria Italiana. (1970). Il Magnifico Agostino Chigi. Roma: Aristide Staderini.

Barbieri, G. (1940). Industria e Politica Mineraria nello Stato Pontificio dal '400 al '600. Roma: Cremonese Libraraio.

Carlo, M. D., et al. (1984). La Società Dell'Allume. Officina Edizione.

Croce, B. (1949). Le allumiere di Agnano nei secoli XV e XVI e la Santa Sede. In Scritti di Storia Letteraria e Politica (Vol. XXIX, pp. 35-41). Bari: Lius. Laterza and Figli.

de Roover, R. (1946). The Medici Bank financial and commercial operations. Journal of Economic History, 6(2), 153-172.

de Roover, R. (1966). The rise and decline of the Medici Bank 1397-1497. New York: W. W. Norton.

Deák, F. (1936). Contracts and combinations in restraint of trade under french law: A comparative study. Iowa Law Review, 21, 397-454.

Delumeau, J. (1962). L'Alun de Rome XVe-XIXe Siècle. S.E. V.P.N.

Franchini, V. (1950). Note sull'attivita finanziaria di Agostino Chigi nel Cinquecento (pp. 156-175). Milan: Studi in Onore di Gino Luzzatto. II.

Freedeman, C. E. (1988). Cartels and the law in France before 1914. French Historical Studies, 15, $462-478$.

Gerber, D. J. (1998). Law and competition in twentieth century Europe: Protecting prometheus. Oxford: Clarendon Press.

Gilbert, F. (1980). The Pope, His Banker, and Venice. Cambridge, MA: Harvard University Press.

Gottlob, A. (1889). Aus Der Camera Apostolica Des 15 Jahrhunderts: Ein Beitrag Zur Geschichte Des Papstlichen Finanzwesens Und Des Endenden Mittelalters. Wagner: Innsbruck.

Heers, M.-L. (1954). Les Génois et le commerce de l'alun à la fin du Moyen Age. Revue d'Histoire Economique et Sociale, 32, 31-53.

Kleinwächter, F. (1883). Die Kartelle. Innsbruck: Verlag der Wagner'schen Universitets-Buchhandlung.

Mallett, M. (1998). The Northern Italian States. In C. Allmand (Ed.), The New Cambridge medieval history (pp. 547-570). Cambridge: Cambridge University Press.

Mantenovesi, O. (1937). Agostino Chigi, banchiere e appaltatore dell'allume di Tolfa. Archivio della R. Deputazione romana di storia patria (pp. 107-147).

Martines, L. (2003). April blood: Florence and the plot against the Medici. Oxford: Oxford University Press.

Maschke, E. (1968). Deutsche Kartelle im späten Mittelalter und im 19. Jahrhundert vor 1870. In Friedrich Lütge, editor, Wirtschaftliche und soziale Probleme der gewerblichen Entwicklung im 15.16. Und 19. Jahrhundert (pp. 102-114). Stuttgart: Gustav Fischer Verlag.

Mignanti, F. M. (1936). Santuari della Regione di Tolfa. Memorie Storiche, a cura di Ottorino Morra, Roma, Cremonese, 1936.

Morsel, H. (1976). Contribution à l'histoire des ententes industrielles. Revue d'Histoire Économique et Sociale, 54, 118-129.

Nef, J. U. (1941). Industrial Europe at the time of the Reformation (ca. 1515-ca. 1540). Journal of Political Economy, 49, 1-40.

Pastor, L. (1949). History of the Popes, fifth edition (translated from German) (Vol. IV). London: Routledge and Kegan Paul.

Pipino, G. (2009). Oro e allume nella storia dell'isola d'Ischia. La Rassegna d'Ischia 18-36, June.

Pius II (Piccolomini, Enea Silvio Bartolomeo) (1962). Commentaries. Translated by Florence A. Gragg. Edited by Leona C. Gabel. New York: Capricorn Books.

Rénaud, F. (1960). Le cartel des cristaux, 1830-1857. Histoire des Entreprises, 5, 7-20.

Riesenfeld, S. A. (1960). The legal protection of competition in France. California Law Review, 48, 574-595.

Rosenberg, H. (1943). Political and social consequences of the great depression of 1873-1896 in Central Europe. Economic History Review, 13, 58-73. 
Rowland, I. D. (1986). Render unto Caesar the things which are Caesar's: Humanism and the arts in the patronage of Agostino Chigi. Renaissance Quarterly, 39, 673-730.

Ryder, A. (1998). The Papal States and the Kingdom of Naples. In C. Allmand (Ed.), The New Cambridge Medieval History (pp. 571-587). Cambridge: Cambridge University Press.

Schnerb, B. (1998). Burgundy. In C. Allmand (Ed.), The New Cambridge Medieval History (pp. 431-456). Cambridge: Cambridge University Press.

Schröter, H. G. (1996). Cartelization and decartelization in Europe, 1870-1995: Rise and decline of an economic institution. Journal of European Economic History, 25, 129-153.

Singer, C. J. (1948). The earliest chemical industry: An essay on the historical relations of economics and technology illustrated from the alum trade. London: Folio Society.

Strieder, J. (1925/1971). Studien zur Geschichte kapitalististischer Organisationsformen. Second edition, München and Leipzig, 1925, reprinted New York: Lenox Hill Pub. and Dis. Co. (Burt Franklin).

Tan, E. S. (2009). Market structure and the coal cartel in early nineteenth-century England. Economic History Review, 62, 350-365.

Theiner, A. (1862). Codex diplomaticus dominii temporalis S. Sedis. III. Rome, pp. 463-467, no. 398.

Voight, F. (1962). German experience with cartels and their control during pre-war and post-war periods. In J. P. Miller (Eds.), Competition cartels and their regulation (pp. 169-213). Amsterdam: North Holland.

von der Ropp, G. (1901). Zür geschichte des Alaunhandels im 15 Jahrhundert. Hansische Geschichtsblätter (pp. 119-136).

Zippel, G. (1907). L'allume de Tolfa e il suo commercio. Archivio della R. Società Romana di Storia Patria XXX(I-II):4-51, XXX(III-IV):389-462. 